\title{
EFFECT OF ACUPUNCTURE AND ACUPRESSURE THERAPY \\ ON REDUCTION OF PAIN LEVELS IN LOWER STEP PAIN \\ PATIENTS, DUKUH DUWETAN, CENTRAL JAVA
}

\author{
Imrok Atus Sholihah, Sumanto, Risna Widowati \\ Ministry of Health, Surakarta Polytechnic Health Department of Acupuncture
}

\begin{abstract}
Background: The lower limb consists of four major parts: a girdle formed by the hip bones, the thigh, the leg, and the foot. It is specialized for the support of weight, adaptation to gravity, and locomotion. Acupuncture involves the insertion of needles into specific points in the body by a licensed acupuncturist. Acupressure uses firm pressure to massage those points, with similar effects. This study aimed to determine effect of acupuncture and acupressure therapy on reduction of pain levels in lower step pain patients, Duwetan, Central Java.

Subjects and method: This study was a experimental study with one Group pretest-posttest conducted in Dukuh Duwetan, Karanganyar Regency, Central Java from February to March. A sample of 30 farmers, both men and women aged 30-50 years with complaints of lower limb pain during and after work, who met the inclusion criteria. The dependent variable was decrease level of pain lower limb. The independent variable was effect of the stabbing and emphasis on points Blader (BL) 57 (Chengsan) and Blader (BL) 40 (Weizhong). The data collected by observation sheet of pain degrees, according to Smeltzer, S.C bare B.G and analysed by Wilcoxon test.

Results: The results of the stabbing and pressing at BL 57 and $\mathrm{BL} 40$ points $(\mathrm{Mean}=1 ; \mathrm{SD}=$ 0.71 ) were lower than before therapy (Mean $=6 ; \mathrm{SD}=1.21$ ), there was a decrease in the pain scale with lower limb. After stabbing and suppression were applied $(\mathrm{OR}=7.85 ; 95 \% \mathrm{CI}=0.0$ to $2.0 ; \mathrm{p}$ $<0.001$ ).
\end{abstract}

Conclusion: There is an effect of acupuncture and acupressure therapy on lower leg pain reduction.

Keywords: lower limb, acupuncture, acupressure

\section{Correspondence:}

Imrokatus Sholihah. Ministry of Health, Surakarta Polytechnic Health Department of Acupuncture. Jl. Letjen Sutoyo, Mojosongo, Jebres disctrict, Surakarta, Central java 57127 Email: imrokatussholihah6@gmail.com Mobile: +62811225210.

The $7^{\text {th }}$ International Conference on Public Health

Solo, Indonesia, November 18-19, 2020 388 https://doi.org/10.26911/the7thicph.05.20 